\title{
Computer Programs for P-T History of Metamorphic Rocks using Pseudosection Approach
}

\author{
T. N. Jowhar \\ Wadia Institute of Himalyan \\ Geology, Dehradun 248001, \\ India
}

\begin{abstract}
In this paper computer program THERMOCALC, GIBBS and THERIAK-DOMINO are discussed and pseudosections are generated on some chemical data taken from the published literature from the Himalaya and Alps and also new chemical and EPMA data generated from the Garhwal Himalaya to demonstrate the capabilities of THERMOCALC and THERIAK-DOMINO. Usefulness and limitations of computed pseudosections (equilibrium assemblage diagrams) with THERIAK-DOMINO and THERMOCALC in understanding evolutionary history of metamorphic rocks are discussed
\end{abstract}

\section{Keywords}

Geothermobarometry, P-T estimates, Pseudosection, Himalaya, Metamorphic rocks, THERMOCALC, GIBBS, THERIAK-DOMINO

\section{INTRODUCTION}

Retrieval of pressure-temperature-time (P-T-t) history of metamorphic rocks and the constraints that it imposes in the reconstruction of the tectono-metamorphic evolution of rocks in different tectonic regimes have been among the central themes of metamorphic petrology for a long time. The quality of the internally consistent thermodynamic data set of mineral end-member properties has improved considerably in the last twenty-five years [1] [2] [3] [4]. The better knowledge of the activity-composition (a-X) relationships for minerals, silicate liquid and fluid phases allows more reliable petrological calculations. Pressure-temperature history of metamorphic rocks can be evaluated using conventional methods or by using pseudosection approach. A pseudosection, also called an equilibrium phase diagram, is a type of phase diagram that shows the fields of stability of different equilibrium mineral assemblages for a single-bulk rock composition. Pseudosections are generally simpler and much easier to interpret than standard phase diagrams that show many reactions. Conventional geothermobarometry (inverse modeling) uses the equilibrium thermodynamics of balanced chemical reactions between end-members of minerals, combined with the observed compositions of minerals [5] [6] [7]. Whereas in contrast, pseudosections involve a forward calculation of mineral equilibria for a given rock composition. Contrary to petrogenetic grids or thermobarometry results, the attention here is not on single/multiple reactions but on equilibrium assemblages. The equilibrium volume plays an important role in pseudosection thermobarometry, because it is the chemical composition of the equilibration volume that is used in the calculations. However, thermobarometry and pseudosections (equilibrium assemblage diagrams) are complementary tools and should be used together. Pseudosections provide a certain confidence on stable assemblages and provide important information constraining P-T paths and thermobarmetry provides reliable P-T estimates for specific points on a P-T path. The advantage of pseudosections is that calculated mineral compositions can be looked at directly. Also pseudosections are powerful tools to: (1) check and visualize the implications of thermodynamic databases; (2) develop new equations of state and solution models; (3) plan new experimental work and (4) understand natural systems. In this paper computer program THERMOCALC [8] [9], GIBBS [10] [11] [12] and THERIAK-DOMINO [13] are discussed and pseudosections are generated on some chemical data taken from the published literature from the Himalaya and Alps and also new chemical and EPMA data generated from the Garhwal Himalaya to demonstrate the capabilities of THERMOCALC and THERIAK-DOMINO.

It should be noted that pseudosection always relate to a specific bulk composition. They illustrate which assemblages would theoretically be stable at equilibrium. Therefore, pseudosections do not exactly describe what happens in nature, these diagrams only serve as models that help in understanding geological processes. Many metamorphic rocks show a dominant assemblage, which is believed to have formed around peak metamorphic conditions. If the rock has reached equilibrium and post-peak processes have not modified the mineral compositions, then construction of Pseudosection with THERIAK-DOMINO or THERMOCALC helps to constrain the P-T conditions for this assemblage. Further information that can be deduced from Pseudosection include precursor minerals, P-T ranges for relics and constraints on the post-peak path.

\section{COMPUTER PROGRAMS FOR P-T CALCULATIONS AND CONSTRUCTION OF PSEUDOSECTIONS}

Among the numerous computer programs for P-T calculations and pseudosections, five are particularly popular and in common use: (i) TWQ (Berman, 2007) [5] (ii) THERMOCALC (Powell et al., 1998; Powell and Holland, 2001) [8] [9] (iii) THERIAK-DOMINO (De Capitani and 
Petrakakis, 2010) [13] (iv) GIBBS (Spear and Menard, 1989; Spear et al. 1991, 2001) [10] [11] [12] and (v) PERPLE_X (Connolly, 1990, 2005) [14] [15].

1. THERMOCALC [8] [9] [16] is a thermodynamic calculation software for tackling mineral equilibria problems. It has two main components: the application itself, and the internally-consistent thermodynamic dataset it uses. The mineral equilibria problems that can be addressed with THERMOCALC include inverse modelling (geothermometry/barometry using average PT), and forward modelling (calculating phase diagrams for model systems). THERMOCALC and associated program AX and DRAWPD are written in Pascal using Metrowerks Codewarrior on the Mac platform, and Delphi on the PC platform. The PC development is done on the Mac using the emulsion software, RealPC, running Windows 95. The first thermodynamic calculation program with the name THERMOCALC (in FORTRAN language) was written by Roger Powell in 1971. It went through various modifications over the years from mainframes to Hewlett-Packard programmable calculators.

The latest version of THERMOCALC (version 3.33 dated 26/10/09) can be downloaded from the THERMOCALC resources webpage:

http://www.metamorph.geo.uni-mainz.de/thermocalc

This page is housed at The Johannes Gutenberg University of Mainz is a collaborative effort between Roger Powell (University of Melbourne), Tim Holland (Cambridge University) and Richard White (University of Mainz) to provide a much-expanded set of THERMOCALC resources.

THERMOCALC, being backwards-compatible, works with the various generations of dataset, so it is usually appropriate to use the current version of THERMOCALC, as available from the above mentioned web site.

2. Computer program GIBBS by Spear and Menard (1989) [10] is a routine coded in FORTRAN that has been designed to perform generalized Gibbs method (Spear et al., 1982) [17] calculations. The present program is the successor to the P-T PATH program of Spear (1986) [18], which computed pressure-temperature paths from zoned garnets. The Gibbs method is a procedure that uses a Jacobian transformation to compute changes (i.e. finite differences) in a set of dependent thermodynamic variables, given the changes in a set of independent thermodynamic variables. The thermodynamic variables are the derivatives of $\mathrm{T}$ (temperature), $\mathrm{P}$ (pressure), $\mu$ (chemical potential), $X$ (composition) and $M$ (the number of moles of a phase in an assemblage).

The power of the GIBBS program lies in the fact that the choice of independent variables is completely arbitrary. Therefore, a variety of petrologic problems may be addressed by this method. Following problems have been examined by Gibbs method [19] [20]: (i) calculation of metamorphic P-T paths from zoned garnets (ii) analysis of the phase equilibria of metamorphic systems (iii) analysis of the effects of fractional crystallization on the evolution of metamorphic mineral assemblages (iv) calculation of a petrogenetic grid for pelitic schists.

Spear et al. (1991) [11] developed computer programs for Apple Macintosh computer that are designed to facilitate metamorphic petrology calculations and to explore the tectonic significance of P-T-t paths through thermal modelling. GIBBS 90 is a general Gibbs method algorithm, similar to the program described by Spear and Menard (1989) [10]. This version is enhanced considerably and includes (a) complete compatibility with Berman's (1988) [1] thermodynamic data base, (b) generalized Margules nonideal mixing for single-site solid solutions, (c) calculations involving mixed volatile equilibria $\left(\mathrm{H}_{2} \mathrm{O}-\mathrm{CO}_{2}\right)$, (d) a "user friendly" Macintosh interface, (e) on-screen graphics plotting, (f) support of encapsulated Post Script graphics output, (g) a completely rewritten computational algorithm involving equilibrium constants rather than Gibbs-Duhem equations, which simplifies matrix calculations and enhances speed by a factor of 2-4, and (h) the option of open system calculations. The program is designed to calculate $\mathrm{P}-\mathrm{X}, \mathrm{T}-\mathrm{X}$ and $\mathrm{P}-\mathrm{T}$ contour diagrams, P-T paths from zoned garnets, prograde reaction path models, and other petrologic phase equilibria.

3. THERIAK-DOMINO software (De Capitani and Petrakakis, 2010) [13] allows to compute completely and automatically a variety of diagrams like phase diagrams, pseudosections, pseudo-binary, pseudo-ternary, isopleths, modal amounts, molar properties of single phases or bulk properties like total $\Delta \mathrm{G}$ etc. DOMINO is a part of the THERIAK-DOMINO software package that consists of 10 programs. The core of the program package is THERIAK which calculates equilibrium assemblages for a given bulkrock composition at any $\mathrm{P}$ and $\mathrm{T}$. The strategy of THERIAK is linear programming combined with minimization of single thermodynamic solution functions and is designed to produce the correct assemblage even for complex non-ideal systems. In an equilibrium assemblage diagram (Pseudosection) prepared by THERIAK-DOMINO, each point defines a unique bulk composition, $\mathrm{P}$ and $\mathrm{T}$. The diagram maps the predicted assemblages based on Gibbs free energy minimization. Contrary to petrogenetic grids, a corresponding equilibrium assemblage diagram is valid only for a particular bulk-rock composition. The stability fields calculated by DOMINO are based on Gibbs free energy minimization rather than solving complex system of equations. This technique used in THERIAK-DOMINO reflects the fundamental principle of thermodynamics that relates stability of an assemblage with minimal energy content.

The THERIAK-DOMINO software [13] (latest version 03.01.2012) with source code and examples is available from:

http://titan.minpet.unibas.ch/minpet/theriak/theruser.html 


\section{EXAMPLES OF P-T ESTIMATES AND CONSTRUCTION OF PSEUDOSECTION}

Figure 1 and 2 shows test run of pseudosection (equilibrium assemblage diagram) constructed using THERIAK-DOMINO software for metapelite sample no. TN205 from the staurolite zone in the eastern Alps [21] with database jun92.bs and tcdb55c2d respectively. Sample TN205 contains garnet, white mica, biotite, staurolite, paragonite, plagioclase, quartz, chlorite and accessory ilmenite, rutile and apatite. The matrix assemblage is Grt-Ms-Bt-Qtz-Pl-St. Relics of high pressure assemblage are Grt-Ms-Pg-Qtz. In sample no. TN205, the matrix assemblage Grt-Ms-Bt-Qtz-Pl-St is found in Figure 1 at around $600^{\circ} \mathrm{C}$ and $7 \mathrm{kbar}$. The relic high pressure assemblage Grt-Ms-Pg-Qtz occupies a large stability field above 14 kbar. This pseudosection suggest an overall decompression at ca. $600^{\circ} \mathrm{C}$ from 14 to $7 \mathrm{kbar}$.

Nandini and Thakur (2011) [22] reported classical Barrovian inverted metamorphism in the Lesser Himalayan Crystalline Sequence (LHCS) from the Siyom Valley, NE Himalaya. This sequence is thrust-bounded and constitutes a part of the western limb of the Siang antiform. Six metamorphic zones are delineated with increasing grade from biotite zone through garnet, staurolite, kyanite, sillimanite to sillimanite-k-feldspar zone with increasing structural level. Geothermobarometric calculations show gradual increase of temperature from garnet zone to sillimanite-k-feldspar zone, whereas pressure increases sharply from garnet zone to staurolite zone and remains nearly constant thereafter. Peak metamorphism reached temperature of $>750^{\circ} \mathrm{C}$ and pressure of about $10 \mathrm{kbar}$ in the sillimanite-k-feldspar zone.

In order to understand the metamorphic evolution of the LHCS in the Siyom Valley, P-T pseudosections in the KFMASH system were constructed by Nandini and Thakur (2011) [22] for samples from the staurolite zone and sillimanite-k-feldspar zone using the Perplex software of Connolly (1990, 2005)[14][15]. For the stauroloie zone sample H66, a comparison of the stability field of peak metamorphic assemblage $\mathrm{St}+\mathrm{Grt}+\mathrm{Bt}+\mathrm{Ms}+\mathrm{Qtz}$ in the psedosection (Fig. 4 of Nandini and Thakur, 2011) [22] and P$\mathrm{T}$ values from different geothermobarometers shows good agreement.

Figure 3 shows psedosection constructed using THERIAKDOMINO software [13] in this study for sample no. H66 from Siyom Valley, NE Himalaya with chemical data taken from Nandini and Thakur (2011) [22]. Figure 3 pseudosection is in good agreement with pseudosection constructed by Nandini and Thakur (2011) [22] using Perplex software of Connolly (1990, 2005) [14] [15]. P-T estimates, decompression reactions and pseudosection suggest a clockwise path with steep decompression for the evolution of the sillimanite-kfeldspar zone in the Siyom Valley.

P-T estimates have been done on twenty samples from the Higher Himalayan Crystallines (HHC) in the Garhwal Himalaya along Sainj-Bhatwari-Lohari Nag-Gangotri section in order to place quantitative constraints on the conditions attained during the regional metamorphism. The HHC is comprised of an association of garnet biotite schist, amphibolite, granite gneiss and a undeformed metadolerite of the Bhatwari group in the lowermost parts. This sequence is overridden by the Harsil Group metamorphics along the vaikrita Thrust with the intervening phyllonite and intensely sheared actinolite schist. These metamorphics contain garnetbiotite schist, staurolite-kyanite and sillimanite bearing schist and gneiss, calc-silicate, amphibolite and migmatites. The Gangotri leucogranite (Bhagirathi leucogranite) is situated structurally above the kyanite and sillimanite gneisses of the Vaikrita Group which in turn overlie the north-dipping Main Central Thrust Zone of inverted metamorphic isograds. A pegmatite-aplite leucogranite sill and dyke swarm is present around the margins of the leucogranite. Compared to other High Himalayan leucogranites it is particularly rich in tourmaline. These tourmaline leucogranites cut the foliation of the surrounding older biotite granite and two mica porphyritic granite (Bhaironghati granite) [23].

The EPMA data were obtained on twenty samples by utilizing Cameca SX100 microprobe at Wadia Institute of Himalayan Geology, Dehradun. A probe current of 20nA at an accelerating voltage of $15 \mathrm{Kev}$ and a beam size of one micron were used. Standardization was conducted against natural standards using ZAF corrections. P-T calculations were carried out using computer program TWQ version 2.34 [5], WEBINVEQ [24], BGT [6] and THERMOCALC [8]. These studies reveal increase in both pressure and temperature across the Main Central Thrust (MCT) from south to north. Temperature increases from 500 to $750{ }^{\circ} \mathrm{C}$ and pressure from 6 to $10 \mathrm{kbar}$ across the MCT zone. Spatial distribution of the $\mathrm{P}-\mathrm{T}$ data indicates inverted metamorphism. Figure 4 is the pseudosection (equilibrium assemblage diagram) constructed using THERIAK-DOMINO software [13] with database tcdb55c2d for metapelite sample no. UG77 $(\mathrm{P}=6.9 \mathrm{kbar}, \mathrm{T}=$ $624^{\circ}$ C) garnet kyanite mica schist, from Lohari Nag-Sukhi from Higher Himalayan Crystalline zone of Garhwal Himalaya. Computations on estimation of uncertainties on these P-T estimates using Monte Carlo method and numerical error analysis is under progress [25].

\section{CONCLUSIONS}

In this paper, pseudosections are generated using some chemical data taken from the published literature from the Himalayas and Alps and also new data generated from the Garhwal Himalaya to demonstrate the capabilities of THERIAK-DOMINO and THERMOCALC. Usefulness and limitations of computed pseudosections (equilibrium assemblage diagrams) with THERIAK-DOMINO and THERMOCALC in understanding evolutionary history of metamorphic rocks are discussed. The advantage of the THERIAK-DOMINO software over THERMOCALC is that it is not attached to any specific database and diagram construction is fully automatic, fast and easy to use. The stability fields calculated by DOMINO are based on Gibbs free energy minimization rather than solving complex system of equations. The technique used in THERIAK-DOMINO reflects the fundamental principle of thermodynamics that relates stability of an assemblage with minimal energy content.

\section{ACKNOWLEDGMENTS}

The facilities and encouragement provided by Professor Anil K. Gupta, Director, Wadia Institute of Himalayan Geology, Dehradun, to carry out this research work is thankfully acknowledged.

\section{REFERENCES}

[1] Berman, R. G. 1988. Internally-consistent thermodynamic data for minerals in the system $\mathrm{Na}_{2} \mathrm{O}-\mathrm{K}_{2} \mathrm{O}-\mathrm{CaO}-\mathrm{MgO}-\mathrm{FeO}-$ $\mathrm{Fe}_{2} \mathrm{O}_{3}-\mathrm{Al}_{2} \mathrm{O}_{3}-\mathrm{SiO}_{2}-\mathrm{TiO}_{2}-\mathrm{H}_{2} \mathrm{O}-\mathrm{CO}_{2}$. Journal of Petrology, vol. 29 , no.2, 445-522.

[2] Holland, T. J. B. and Powell, R. 1990. An enlarged and updated internally consistent thermodynamic dataset with 
uncertainties and correlations: the system $\mathrm{K}_{2} \mathrm{O}-\mathrm{Na}_{2} \mathrm{O}-\mathrm{CaO}-$ $\mathrm{MgO}-\mathrm{MnO}-\mathrm{FeO}-\mathrm{Fe}_{2} \mathrm{O}_{3}-\mathrm{Al}_{2} \mathrm{O}_{3}-\mathrm{TiO}_{2}-\mathrm{SiO}_{2}-\mathrm{C}-\mathrm{H}_{2}-\mathrm{O}_{2}$. Journal of Metamorphic Geology, 8, no.1, 89-124.

[3] Holland, T. J. B. and Powell, R. 1998. An internally consistent thermodynamic dataset for phases of petrological interest. Journal of Metamorphic Geology, 16, no.3, 309-343.

[4] Holland, T. J. B. and Powell, R. 2011. An improved and extended internally consistent thermodynamic dataset for phases of petrological interest, involving a new equation of state for solids. Journal of Metamorphic Geology, vol. 29, no.3, 333-383.

[5] Berman, R. G. 2007. WinTWQ (version 2.3): A software package for performing internally-consistent thermobarometric calculations. Geological Survey of Canada Open File 5462(revised), 41pp.

[6] Jowhar, T. N. 1999. BGT: A FORTRAN 77 computer program for biotite-garnet geothermometry. Computers and Geosciences, vol. 25, no. 5, 609-620.

[7] Jowhar, T. N. 2001. Geobarometric constraints on the depth of emplacement of granite from the Ladakh batholith, Northwest Himalaya, India. Journal of Mineralogical and Petrological Sciences, vol. 96, no. 2, 256-264.

[8] Powell, R. and Holland, T. J. B. 2001. Course notes for THERMOCALC workshop 2001: Calculating Metamorphic Phase Equilibria (on CD-ROM).

[9] Powell, R., Holland, T. J. B. and Worley, B. 1998. Calculating phase diagrams involving solid solutions via nonlinear equations, with examples using THERMOCALC. Journal of Metamorphic Geology, vol. 16, no. 4, 577-588.

[10] Spear, F.S. and Menard, T. 1989. Program GIBBS: a generalized Gibbs method algorithm. American Mineralogist, vol. 74, nos. 7-8, 942-943.

[11] Spear, F.S., Peacock, S.M., Kohn, M.J., Florence, F.P. and Menard, T. 1991. Computer programs for petrologic P-T-t path calculations. American Mineralogist, vol. 76, nos. 11-12, 2009-2012.

[12] Spear, F. S., Pyle, J. M. and Storm, L. C. 2001. Short course: Thermodynamic modeling of mineral reactions: An introduction to Program Gibbs. Northeast Section, Geological Society of America, Vermont.

[13] De Capitani, C. and Petrakakis, K. 2010. The computation of equilibrium assemblage diagrams with Theriak/Domino software. American Mineralogist, vol. 95, no.7, 1006-1016.
[14] Connolly, J. A. D. 1990. Multivariable phase diagrams: An algorithm based on generalized thermodynamics. American Journal of Science, vol. 290, no. 6, 666-718.

[15] Connolly, J. A. D. 2005. Computation of phase equilibria by linear programming: a tool for geodynamic modeling and its application to subduction zone decarbonation. Earth and Planetary Science Letters, vol. 236, nos. 1-2, 524-541.

[16] Jowhar, T. N. 2005. Computer programs for P-T calculations and construction of phase diagrams: Use of TWQ, WEBINVEQ and THERMOCALC. In: Antarctic Geoscience, Ocean-Atmosphere interaction and Paleoclimatology (Eds. S. Rajan and P. C. Pandey), National Centre for Antarctic \& Ocean Research, Goa, pp. 248-262.

[17] Spear, F. S., Ferry, J. M., and Rumble, D. 1982. Analytical formulation of phase equilibria: the Gibbs method. In: Characterization of metamorphism through mineral equilibria (Ed. J. M. Ferry), Mineralogical Society of America, Reviews in Mineralogy, vol. 10, 105-152.

[18] Spear, F. S. 1986. PTPATH: A FORTRAN program to calculate pressure-temperature paths from zoned metamorphic garnets. Computers and Geosciences, vol. 12, no.3, 247-266.

[19] Jowhar, T. N. 2007. Pressure-Temperature paths from zoned metamorphic garnets. Indian Journal of Geochemistry, vol. 22 , no. $2,419-429$.

[20] Spear, F. S. and Selverstone, J. 1983. Quantitative P-T paths from zoned minerals: Theory and tectonic applications. Contributions to Mineralogy and Petrology, vol. 83, 348-357.

[21] Nagel, T., De Capitani, C. and Frey, M. 2002. Isograds and P-T evolution in the eastern Lepontine Alps (Graubunden, Switzerland). Journal of Metamorphic Geology, vol. 20, no. 3, 309-324.

[22] Nandini, P. and Thakur, S.S. 2011. Metamorphic evolution of the Lesser Himalayan Crystalline Sequence, Siyom Valley, NE Himalaya, India. Journal of Asian Earth Sciences, vol. 40, no.5, 1089-1100.

[23] Jowhar, T. N. 2010. Chemistry of tourmalines from the Gangotri Granite, Garhwal Higher Himalaya. E-Journal of Earth Sciences, vol. 3, no. 3, 181-194.

[24] Gordon, T. M. 1998. WEBINVEQ THERMOBAROMETRY: An experiment in providing interactive scientific software on the World Wide Web. Computers and Geosciences, vol. 24, no. 1, 43-49.

[25] Jowhar, T. N. 2012. Methods for estimation of uncertainties in geothermobarometry . In: Advances in intelligent and soft computing series of Springer (Eds. Kusum Deep, Atulya Nagar, Millie Pant and J.C. Bansal ), vol.131, pp. 481-492. 
09/07/2011 22:06:34 CPU-Time (hhh:mm:sec): 000:28:02.923

domino version: 01.08 .09

database: jun92.bs

$\mathrm{Ab}: \mathrm{ABSAL}$

H2O: HAAR

OLIVINEi: ideal

SPIN: ideal+margules

GARNET: site mixing+margules

FSP: external+margules

BIOTITE: ideal

Sample no. TN 205

Bulk(1)= SI(380.19)AL(230.56)FE(47.03)MG(18.57)CA(8.08)NA(34.88)K(35.71)H(244.98)O(?)

All assemblages coexist with excess quartz and water

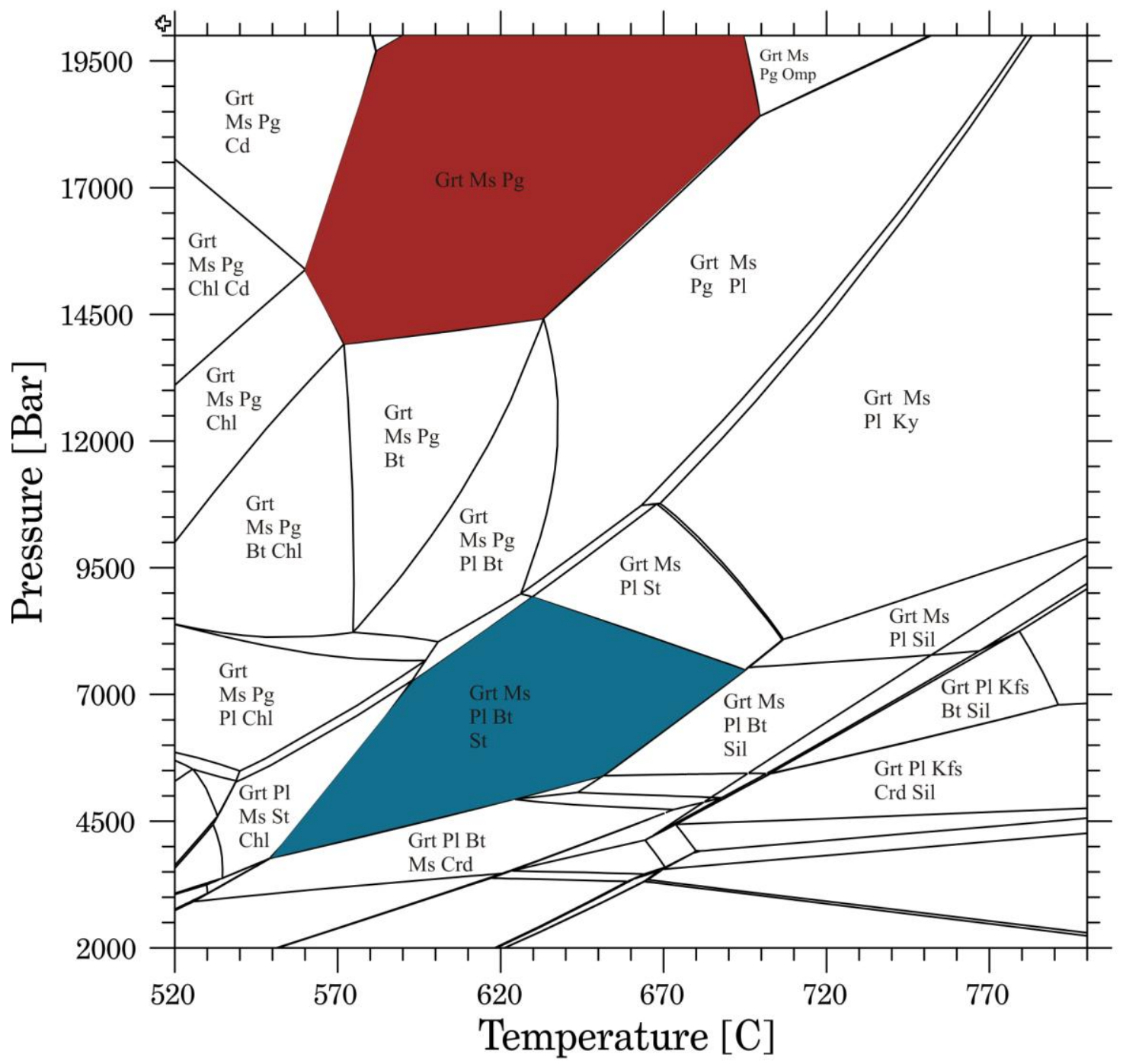

Figure 1. Example of pseudosection constructed using THERIAK-DOMINO software using database jun92.bs (Metapelite sample no. TN 205, chemical data from Nagel et al., 2002)

WHITE MICA: ideal+margules

STAU: site mixing+margules

OPX: ideal

OMPH: ideal+margules

CHL4: ideal

CORD: ideal

OID: idea

EPID: ideal

AMPHx: ideal+margules 
09/07/2011 22:56:16 CPU-Time (hhh:mm:sec): 003:06:48.000

domino version: 01.08.09 database: tcdb55c2d H2O: HHP98

OLIVINEi: ideal

FSP: ideal+margules

GARNET: site mixing+margules $\mathrm{CO}$

OMPH: site mixing+margules

OPX: site mixing+margules

CHTD: ideal+margules

CRPH: ideal

Sample no. TN 205

Bulk(1)= SI(380.19)AL(230.56)FE(47.03)MG(18.57)CA(8.08)NA(34.88)K(35.71)H(244.98)O(?)

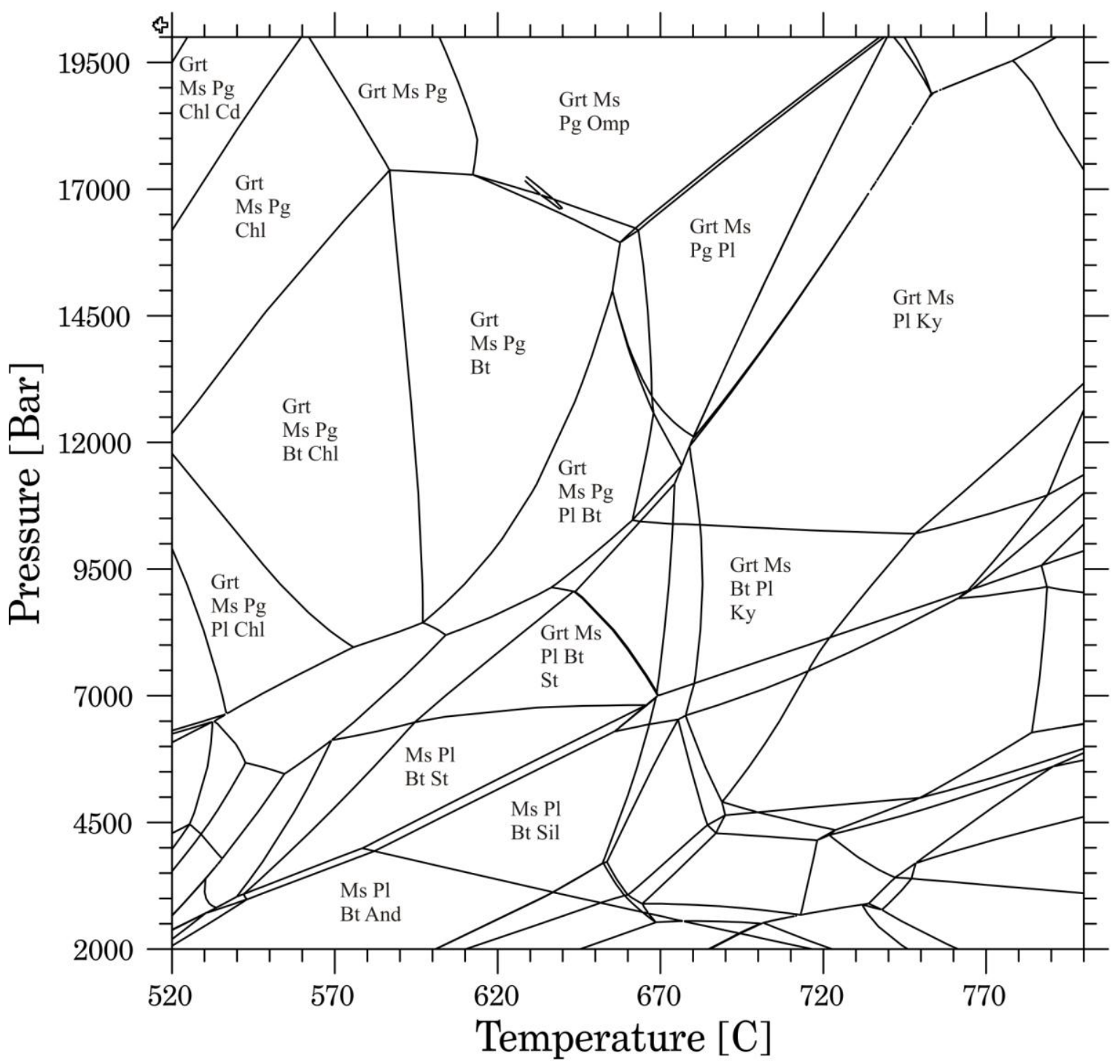

Figure 2. Example of pseudosection constructed using THERIAK-DOMINO software using database tedb55c2d (Metapelite sample no. TN 205, chemical data from Nagel et al., 2002).
: site mixing + margules

PHNG: site mixing + margule

ming+margules

STAU: ideal+margules

CORD: site mixing

PIN: site mixing

SAPP0: site mixing+margules

OSUM0: site mixing

LIQtc: external+margules 
13/07/2011 13:04:39 CPU-Time (hhh:mm:sec): 000:23:12.230

domino version: 01.08 .09 database: $\operatorname{tcdb} 55 \mathrm{c} 2 \mathrm{~d}$ H2O: HHP98

OLIVINEi: ideal

GARNET: site mixing+margules OPX: site mixing+margules

CHTD: ideal+margules

CRPH: ideal

CHLR: site mixing + margules

Sample no. H66

Bulk(1)= SI(396)AL(279)FE(53)MN(0)MG(22)CA(0)NA(0)K(65)TI(0)H(185)O(?)

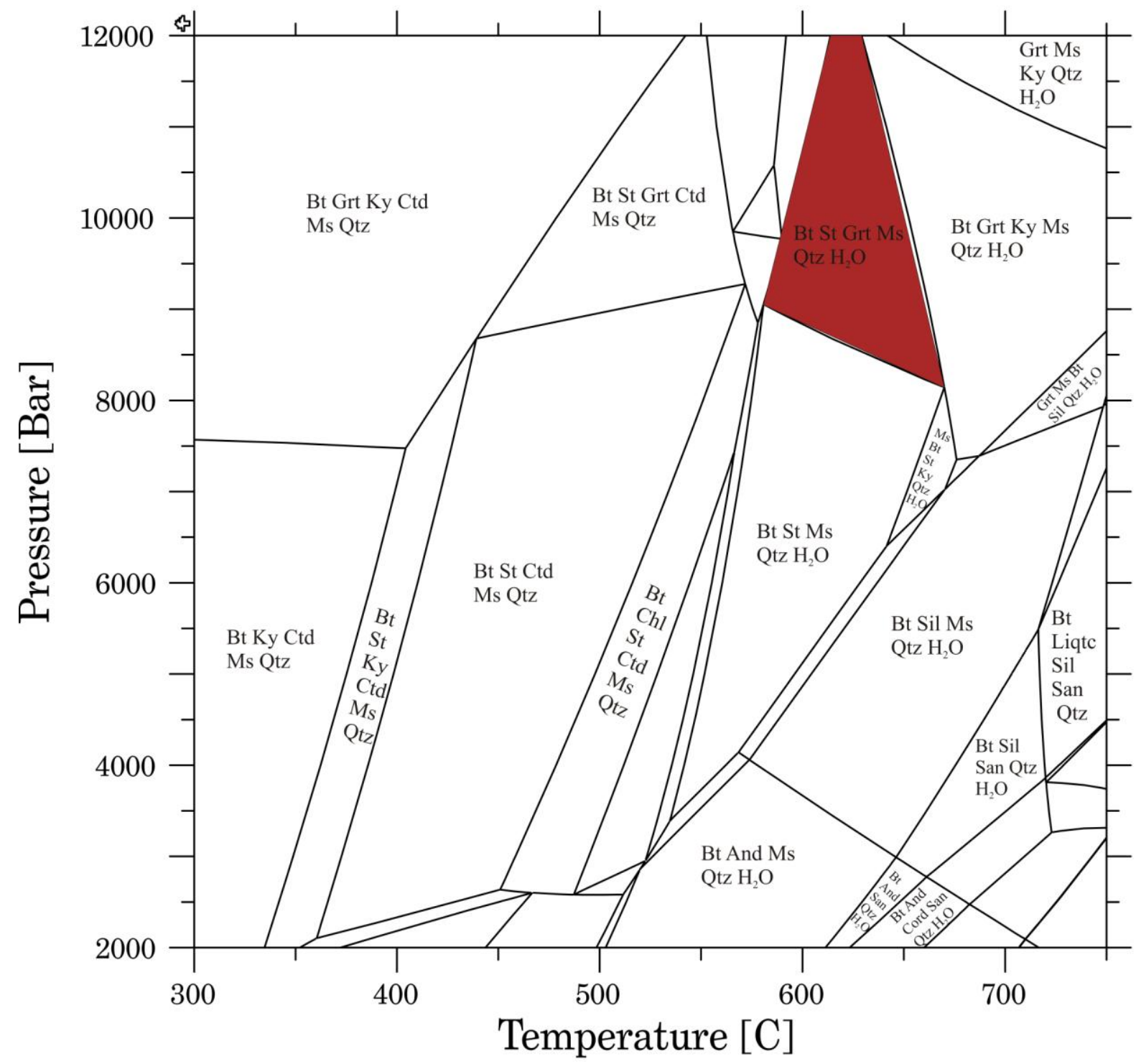

Figure 3 : Pseudosection for sample no. H66 Siyom Valley, NE Himalaya (Nandini and Thakur, 2011) using THERIAK-DOMINO software with tedb55c2d database.

PHNG: site mixing + margules : site mixing+margules

TALC: site mixing

STAU: ideal+margules

ORD: site mixing

SPIN: site mixing

SAPP0: site mixing+margules

OSUM0: site mixing

LIQtc: external+margules 


$\begin{array}{ll}\text { 11/09/2011 18:31:20 CPUTime (hhh:mm:sec): 000:29:53.247 } \\ \text { domino version: 01.08.09 } & \text { PHNG: site mixing+margules } \\ \text { database: tcdb55c2d } & \text { BIO: site mixing+margules } \\ \text { H2O: HHP98 } & \text { TALC: site mixing } \\ \text { OLIVINEi: ideal } & \text { STAU: ideal+margules } \\ \text { GARNET: site mixing+margules } & \text { CORD: site mixing } \\ \text { OPX: site mixing+margules } & \text { SPIN: site mixing } \\ \text { CHTD: ideal+margules } & \text { SAPP0: site mixing+margules } \\ \text { CRPH: ideal } & \text { OSUM0: site mixing } \\ \text { CHLR: site mixing+margules } & \text { LIQtc: external+margules }\end{array}$

Bulk(1)=SI(753.33)AL(136.89) FE(37.41) MN(0)MG(49.45)CA(0)NA(0)K(28.25)TI(0)H(432.10)O(?)

All assemblages coexist with excess quartz and water

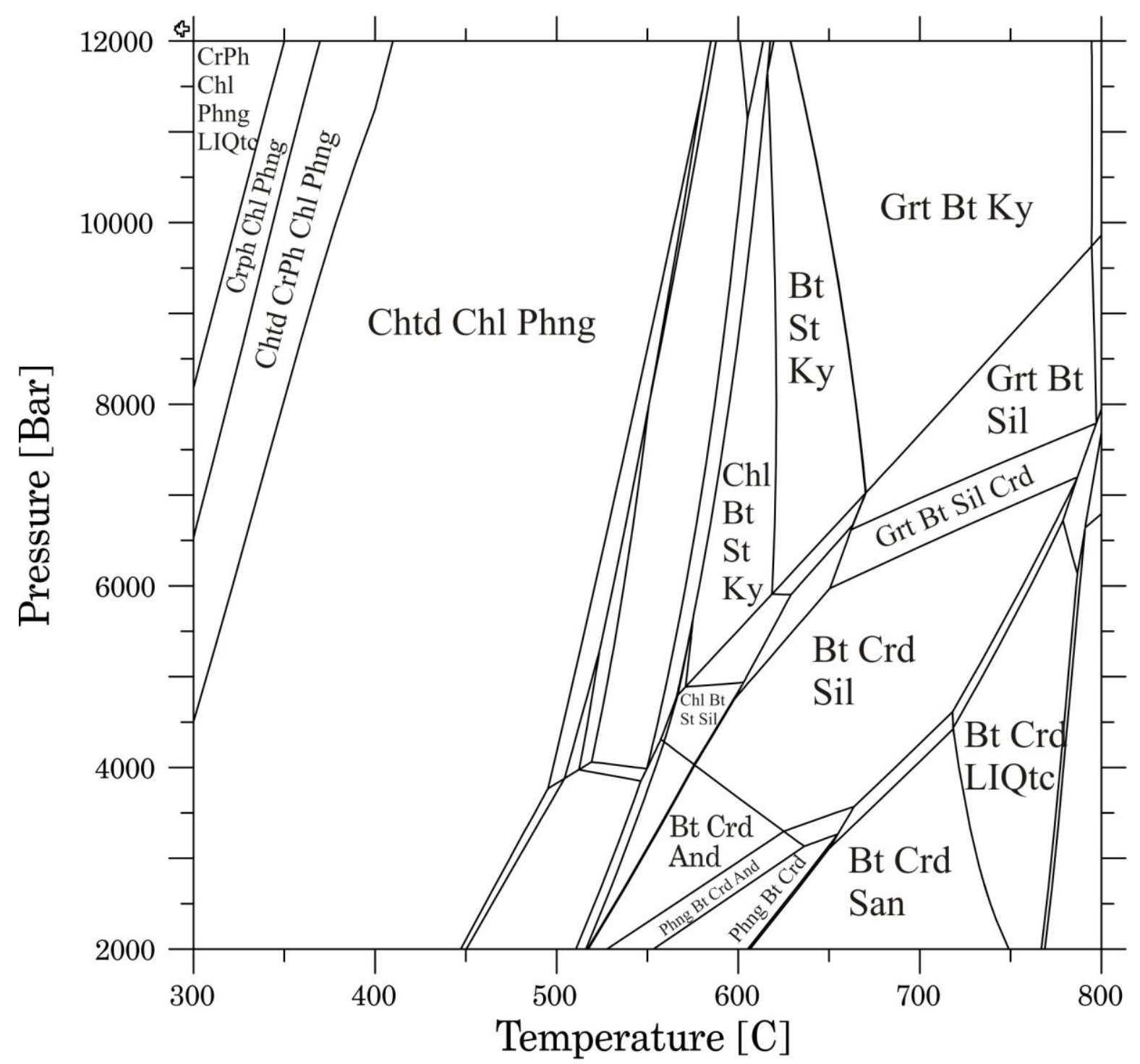

Fig. 4. Pseudosection for sample no. UG77 (Garnet kyanite mica schist; sample location: from Lohari Nag-Sukhi on the Bhatwari-Gangotri road - Higher Himalayan Crystalline Zone of Garhwal Himalaya). Pseudosection constructed using THERIAK-DOMINO software (De Capitani and Petrakakis, 2010). 